\title{
GROWTH AND YIELD OF SUNFLOWER (Helianthus annus \\ L.) AS INFLUENCED BY NITROGEN, SULPHUR AND FARMYARD MANURE UNDER TEMPERATE CONDITIONS
}

\author{
F. U. Rasool ${ }^{1}$, B. Hassan and I. A. Jahangir \\ Sher-e-Kashmir University of Agricultural Sciences and Technology of Kashmir \\ Srinagar- 191 121, India
}

\begin{abstract}
A field experiment was conducted at the Research farm, Division of Agronomy, Sher-e-Kashmir University of Agricultural Sciences and Technology, India for two consecutive rainy (kharif) seasons of 2009 and 2010 to find out the impact of nitrogen, sulphur and farmyard manure (FYM) on growth and yield of sunflower (Helianthus annuus L.). Application of $120 \mathrm{~kg} \mathrm{~N}^{-1}$ significantly increased all the yield components viz., plant height, leaf area index, dry matter production, capitulum diameter, achenes capitulum ${ }^{-1}$ and 1000 -seed weight. Pooled yield increased by $26 \%$ with $120 \mathrm{~kg} \mathrm{~N}$ but it was statistically at par with $80 \mathrm{~kg} \mathrm{~N} \mathrm{ha}^{-1}$. With increased $\mathrm{N}$ dose, the oil content consistently decreased but the oil yield improved during both years. Sulphur application at the rate of $60 \mathrm{~kg} \mathrm{ha}^{-1}$ significantly increased plant height, leaf area index and dry matter production after 25 days of sowing (DAS).All yield contributing characters viz., filled achenes capitulum ${ }^{-1}$, head diameter and 1000-seed weights were higher with $60 \mathrm{~kg} \mathrm{~S}^{-1}$ over $30 \mathrm{~kg} \mathrm{~S} \mathrm{ha}^{-1}$. Seed and stalk yield with $60 \mathrm{~kg} \mathrm{~S} \mathrm{ha}^{-1}$ were significantly higher than those of $30 \mathrm{~kg} \mathrm{~S}^{-1}$. Similarly, oil content and oil yield with $60 \mathrm{~kg} \mathrm{Sha}^{-1}$ was 2 and $10.5 \%$ over $30 \mathrm{~kg} \mathrm{~S} \mathrm{ha}^{-1}$. Application of FYM at the rate of 10 and $20 \mathrm{t} \mathrm{ha}^{-1}$ was at par with each other but recorded significant improvement in the plant height, leaf area index and dry matter production of sunflower after 25 days of sowing over no FYM. FYM @10 and $20 \mathrm{t} \mathrm{ha}^{-1}$ increased the oil yield by 11 and $5.4 \%$, respectively over no application.
\end{abstract}

Key words: FYM, sulphur, sunflower, nitrogen, yield.

\footnotetext{
${ }^{1}$ Corresponding author email: faisulrasool1@gmail.com
}

Received: 14.11.2012 


\section{INTRODUCTION}

Sunflower (Helianthus annuus L.), an important oilseed crop, contains a good percentage of oil (48-53), protein (14-19), crude fibre (16-27), ash (2-3), soluble sugar (7-9) and hull (21-27). Its short duration and photo-insensitivity, suits well for cultivation in rainy season (Thimmegowdaet al., 2007). In India, it is cultivated over an area of about 1.48 million hectares with the production of 0.90 million tones (Anonymous, 2010). It is a recent introduction in Kashmir valley as an oilseed crop, where hardly any oilseed crop is cultivated in kharif season. Nitrogen is the most important limiting nutrient which helps early growth, better assimilation of carbohydrates and synthesis of proteins and as such must be supplied throughout the growth period of the crop. It also affects the seed quality by increasing protein content and decreasing oil concentration (Gudade et al., 2009). Sulphur is increasingly being recognized as the fourth major plant nutrient after nitrogen, phosphorus and potassium (Tandon and Messick, 2002). For higher productivity and sustainability, integrated use of organic and inorganic sources of nutrients is very important (Sharma et al., 2008). Keeping these aspects in view, the present investigation was carried out to study the response of growth and yield of sunflower (Helianthus annuus L.) to different levels of nitrogen, sulphur and farmyard manure under temperate conditions of Kashmir.

\section{MATERIALS AND METHODS}

The field experiment was conducted at the Research farm, Division of Agronomy, Sher-e-Kashmir University of Agricultural Sciences and Technology, India situated between $34^{\circ} .05^{\prime} \mathrm{N}$ latitude and $74^{\circ} .89^{\prime} \mathrm{E}$ longitude at an altitude of 1587 meters above mean sea level for two consecutive rainy (kharif) seasons of 2009 and 2010. Soil was silty clay loam in texture having $1.4 \%$ coarse sand, $18.2 \%$ fine sand, $42.4 \%$ silt and $38 \%$ clay with $\mathrm{pH} 6.5$, organic carbon $0.87 \%$ and available $\mathrm{N}$, $\mathrm{P}, \mathrm{K}$ and S 271.5, 14.3, 160 and $15.7 \mathrm{~kg} \mathrm{ha}^{-1}$, respectively. The precipitation during the cropping season was 177.8 in 2009, and $249.9 \mathrm{~mm}$ in 2010. The experiment was laid out in factorial randomized block design with three replications. The treatments comprised of three nitrogen levels viz., 40,80 and $120 \mathrm{~kg} \mathrm{ha}^{-1}$, two sulphur levels viz., 30 and $60 \mathrm{~kg} \mathrm{ha}^{-1}$ and three FYM treatments viz., 0, 10 and $20 \mathrm{t} \mathrm{ha}^{-1}$. Well decomposed FYM as per treatment was applied to the respective plots and incorporated in the soil. Half dose of $\mathrm{N}$ as per treatment, Phosphorus @ 60 kg ha ${ }^{-1}$ and potassium @ $40 \mathrm{~kg} \mathrm{ha}^{-1}$ were uniformly applied to each plot as a basal dose. Rest of nitrogen was applied in two equal splits at 31 DAS and flowering stage (57 DAS). Nitrogen, phosphorus, potassium and sulphur were applied through urea, diammonium phosphate, muriate of potash and calcium sulphate dehydrated $\left(\mathrm{CaSO}_{4}\right.$ $2 \mathrm{H}_{2} \mathrm{O}$ ), respectively. After opening of furrows, the overnight soaked seed of sunflower variety "Morden"was sown on 24 and 25 June during 2009 and 2010, respectively. The crop was thinned at 15 DAS to retain one seedling per hill at $45 \mathrm{~cm}$ spacing. Light irrigation was given to the crop at the end of June during both the 
years. Five random plants were selected in each treatment, excluding the border row, for taking observation on plant height. The leaf area index was recorded using canopy analyzer (Accu PAR Model LP-80). For dry matter, representative plant samples in penultimate rows of each plot were dried in shade followed by oven drying at $60-65^{\circ} \mathrm{C}$ to a constant weight. Observations on yield parameters were recorded from five randomly selected plants in each treatment. Crop was harvested manually on 24 and 26 September during 2009 and 2010, respectively. Yield was recorded from net plots, leaving border and penultimate rows. The oil content in seed was determined with Nuclear Magnetic Resonance Spectroscope (Ne Port Analyser Model MK III A). Sterility percentage was calculated by the formula:

Sterility percentage $=\frac{\text { Total number of achenes }- \text { number of filled achene }}{\text { Total number of achenes }} \times 100$

\section{RESULTS AND DISCUSSION}

\section{Effect on crop growth}

With the application of $120 \mathrm{kgN} \mathrm{ha}^{-1}$, growth parameters of sunflower viz., plant height, leaf area index and dry matter accumulation were significantly higher with values of $115.9 \mathrm{~cm}, 0.96 \%$ and $7.2 \mathrm{q} \mathrm{ha}^{-1}$ respectively compared to the other two levels of 40 and $80 \mathrm{~kg} \mathrm{~N} \mathrm{ha}^{-1}$ (Table 1) As nitrogen is a major constituent of chlorophyll and proteins, its adequate supply through fertilizer encouraged the photosynthesis, which resulted in better crop growth. Increase in growth attributes in sunflower due to nitrogen application have been reported by Shah and Khanday (2005) and Sarkar and Mallick (2009).

Application of sulphur @ $60 \mathrm{~kg} \mathrm{ha}^{-1}$ recorded 2.3, 23.5 and 12 percent increase in plant height, leaf area index and dry matter production, respectively over $30 \mathrm{~kg} \mathrm{~S}$ $\mathrm{ha}^{-1}$. This could be due to sulphur in regulating the metabolic and enzymatic processes including photosynthesis and respiration. These results are in conformity with the findings of Poomurugesan and Poonkodi (2008). Incorporation of farmyard manure (FYM)@10 or $20 \mathrm{t} \mathrm{ha}^{-1}$ being at par significantly improved growth parameters over the control. The dry matter production with $10 \mathrm{tha}^{-1} \mathrm{FYM}$ was $9.5 \%$ higher over control. This might be due to better crop growth, facilitated by the improvement in soil physical, chemical and biological properties as well as plant nutrition with the addition of organic manure. Similar findings have also been reported by Melo and De-Oliveira (1999) and Ahmad and Jabeen (2009).There were no significant differences between 10 and $20 \mathrm{t} \mathrm{ha}^{-1}$ FYM treatments for plant height, leaf index and dry matter production.

\section{Effect on yield attributes}

Yield attributes viz., capitulum diameter, achenes capitulum ${ }^{-1}$ and 1000 -seed weight increased progressively with increase in nitrogen level up to $120 \mathrm{~kg} \mathrm{ha}^{-1}$ (Table 2). This may be ascribed to the overall improvement in crop vigour and synthesis of sufficient photosynthates with higher availability of nitrogen as 
suggested by Awasthi et al. (2011). Sterility percentage also increased with the increase in nitrogen level. This could be due to increased competition for photosynthates caused by higher number of achenes capitulum ${ }^{-1}$ at higher nitrogen levels. The maximum seed yield of $25.5 \mathrm{q} \mathrm{ha}^{-1}$ was recorded with $120 \mathrm{~kg} \mathrm{~N} \mathrm{ha}^{-1}$. The yield increase could be attributed to the positive response of yield attributes, i.e, ecapitulum diameter and grains/capitulum to nitrogen application. Similar findings were earlier reported by Syed et al., (2006) and Sarkar and Mallick (2009).

Yield contributing characters were significantly influenced by sulphur application. Application of $60 \mathrm{~kg} \mathrm{~S}^{-1}$ significantly increased the head diameter $(12.96 \mathrm{~cm})$, filled achene capitulum ${ }^{-1}(355.7)$ and 1000-seed weight (60.1) over $30 \mathrm{~kg}$ $\mathrm{S} \mathrm{ha}^{-1}$ (Table 2). Seed yield increased significantly to $24.2 \mathrm{q} \mathrm{ha}^{-1}$ with60 $\mathrm{kg} \mathrm{S} \mathrm{ha}^{-1}$. Better partitioning of photosynthates to the reproductive part of the plant could be the reason for these improvements.

Significant increase in yield components and seed yield was observed with application of farmyard manure, which helped better crop growth, produced better yield attributes and ultimately higher seed yield during both the years. Application of 10 and $20 \mathrm{t} \mathrm{ha}^{-1}$ of farmyard manure increased seed yield by 9 and $15 \%$, respectively over no application. These findings are in agreement with those of Manjunatha et al.(2009).

\section{Effect onoil content and oil yield}

Oil content decreased significantly from $40.9 \%$ with $80 \mathrm{~kg} \mathrm{~N}$ to39 \% with 120 $\mathrm{kg} \mathrm{ha}^{-1}$ (Table 2). Higher rates of nitrogen application might have resulted in greater accumulation of protein in plants, reducing the availability of carbohydrates for polymerization into fatty acids, resulting in lower oil content in the seed. Higher oil yield recorded with120 $\mathrm{kg} \mathrm{N} \mathrm{ha}^{-1}$ is due to the higher seed yield. The oil yield improved significantly with increase in nitrogen levels up to $120 \mathrm{~kg} \mathrm{ha}^{-1}$. These results confirm the findings of Aglaveet et al. (2009).

Application of higher level of sulphur significantly increased the oil content and oil yield. Increase in oil content and oil yield with $60 \mathrm{~kg} \mathrm{~S} \mathrm{ha}^{-1}$ was 2 and $10.5 \%$, respectively over $30 \mathrm{~kg} \mathrm{~S} \mathrm{ha}^{-1}$. Similar increase with sulphur application was earlier reported by Rani et al. (2009). There was significant increase in oil content and oil yield due to FYM application with $20 \mathrm{t} \mathrm{ha}^{-1}$ recording the maximum oil yield of 101.1q ha ${ }^{-1}$.

The interaction effect of nitrogen and sulphur, nitrogen and FYM and sulphur and FYM for oil yield was found significant (Table 3). At all levels of nitrogen, the oil yield varied significantly among sulphur and FYM levels and at all levels of sulphur and FYM, the oil yield varied accordingly. Maximum oil yields of 105.6 and $108.1 \mathrm{q} \mathrm{ha}^{-1}$ were recorded with treatment combination $\mathrm{N}_{3} \mathrm{~F}_{3}$ i.e $120 \mathrm{~kg} \mathrm{~N}$ and $20 \mathrm{t}$ FYM ha ${ }^{-1}$ during 2009 and 2010 seasons, respectively. 


\section{CONCLUSION}

Application of 10 toone farmyard manure along with120kg nitrogen and 60kg sulphur per hectare is optimum for higher seed and oil yield of sunflower under temperate Kashmir conditions.

\section{REFERENCES}

Aglave, B. N., Kalegore, N. K., Chavan, M. H. and Jagtap, P. K. 2009. Performance of rainfedrabi sunflower under varied cropping sequence and nitrogen levels. Journal of Soils and Crops, 19 (2): 265-8.

Ahmad, R. and Jabeen, N. 2009.Demonstration of growth improvement in sunflower (Helianthus annuusL.) by the use of organic fertilizers under saline conditions. Pakistan Journal of Botany, 41 (3): 1373-1384.

Anonymous 2010.Agricultural statistics at a glance. . Directorate of economics and statistics, Department of Agriculture and Coorperation, Ministry of Agriculture, GOI, New Delhi.

Awasthi, U. D., Dubey, S. D. and Shripal, 2011.Effect of nitrogen and moisture conservation practices on yield, uptake, water use efficiency and quality of linseed (Linumusitatissimum).Indian Journal of Agricultural Sciences, 81(4): 383-5.

Gudade, B. A., Thakur, M. R., Ulemale, R. B., Imade, S. R. and Bodhade, M. S. 2009.Nutrient uptake, soil nutrient status and quality of new sunflower varieties as influenced by fertilizer levels.Journal of Soils and Crops, 19 (2): 355-9.

Manjunatha, G. S., Upperi, S. N., Pujari, B. T.,Yeledahalli, N. A. and Kuligod, V. B.. 2009.Effect of farm yard manure treated with jeevamrutha on yield attributes, yield and economics ofsunflower (Helianthus annuus L.).Karnataka Journal of Agricultural Sciences, 22 (1): 198-9.

Melo, J.P.L. and De-Oliveira, A.P. 1999.Garlic production as a function of different water levels and bovine manure in soil. Horticultura, Grasileira, 17: 11-15

Poomurugesan, A.V. and Poonkodi, P. 2008.Effect of Sources and Levels of Sulphur on Growth and Yield Performances of Sunflower (Helianthus annuus).Mysore Journal Agricultural Sciences,42(1): 147-153.

Rani, U. K., Sharma, K. L., Nagasri, K., Srinivas, K., Murthy, T.V., Shankar, G.R., Korwar, G.R., Sankar, G.K., Madhavi, M. and Grace, J.K.2009. Response of sunflower to sources and levels of sulphur under rainfed semi-arid tropical conditions.Communication in Soil Science and Plant Analysis, 40: 2926-44.

Sarkar, R. K. and Mallick, R. B. 2009.Effect of nitrogen, sulphur and foliar spray of nitrate salts on performance of spring sunflower (Helianthus annuusL.). Indian Journal of Agricultural Sciences, 79 (12): 986-90.

Shah, A. H. and Khanday, B. A.2005.Response of sunflower (Helianthus annuusL.) to nitrogen and phosphorus under Kashmir valley conditions.SKUAST Journal of Research, 7: 214-8. 
Sharma, K.L., Neelaveni, K., Katyal, J.C., Srinivasa, A., Srinavas, K., Grace, K.J.andMadhavi, M. 2008.Effect of combined use of organic and inorganic sources of nutrients on sunflower yield, soil fertility and overall soil quality in rainfed alfisols .Communications in Soil Science and Plant Analysis,39: 1791-1831.

Syed, T. H., Ganai, M. R., Tahir, A. and Mir, A. H. 2006.Effect of nitrogen and sulphurfertilization on yield and nutrient uptake by sunflower. Journal of Indian Society of Soil Science, 54 (3): 375-6.

Tandon, H. L. S. and Messick, D. L. 2002.Practical sulphur guide. The Sulphur Institute, Washington, D. C.

Thimmegowda, M. N., Nanjapa, H. V. and Ramachandrappa, B. K. 2007. Effect of soil solarization and farmyard manure application on weed control and productivity ofsunflower (Helianthus annuus)-bell pepper (Capsicum annum) sequence. Indian Journal of Agronomy, 52(3): 204-7 
Table 1: Effect of nitrogen, sulphur and FYM levels on growth characters of sunflower

(Pooled over two years)

\begin{tabular}{|c|c|c|c|}
\hline Treatment & $\begin{array}{l}\text { Plant height } \\
\text { (cm) }\end{array}$ & $\begin{array}{l}\text { Leaf Area Index } \\
\text { (LAI) }\end{array}$ & $\begin{array}{c}\text { Dry matter } \\
\text { production }\left(q \text { ha }^{-1}\right)\end{array}$ \\
\hline \multicolumn{4}{|c|}{ Nitrogen levels $\left(\mathrm{kg} \mathrm{ha}^{-1}\right)$} \\
\hline 40 & 106.4 & 0.50 & 6.15 \\
\hline 80 & 112.0 & 0.82 & 6.89 \\
\hline 120 & 115.9 & 0.96 & 7.20 \\
\hline $\mathrm{SE} \pm$ & 1.14 & 0.04 & 0.10 \\
\hline $\mathrm{CD}(\mathrm{p}=0.05)$ & 3.31 & 0.11 & 0.29 \\
\hline \multicolumn{4}{|c|}{ Sulphur levels $\left(\mathrm{kg} \mathrm{ha}^{-1}\right)$} \\
\hline 30 & 110.24 & 0.68 & 6.59 \\
\hline 60 & 112.70 & 0.84 & 7.40 \\
\hline $\mathrm{SE} \pm$ & 0.93 & 0.03 & 0.08 \\
\hline $\mathrm{CD}(\mathrm{p}=0.05)$ & 2.7 & 0.09 & 0.24 \\
\hline \multicolumn{4}{|c|}{ FYM levels $\left(t h a^{-1}\right)$} \\
\hline 0 & 108.57 & 0.62 & 6.31 \\
\hline 10 & 112.50 & 0.82 & 6.91 \\
\hline 20 & 113.38 & 0.84 & 7.01 \\
\hline $\mathrm{SE} \pm$ & 1.14 & 0.04 & 0.10 \\
\hline $\mathrm{CD}(\mathrm{p}=0.05)$ & 3.31 & 0.11 & 0.29 \\
\hline
\end{tabular}


Table 2: Effect of nitrogen, sulphur and FYM levels on yield attributes, seed yield and oil content of sunflower (pooled over two years)

\begin{tabular}{|c|c|c|c|c|c|c|c|}
\hline Treatment & $\begin{array}{c}\text { Capitulum } \\
\text { diameter } \\
\text { (cm) }\end{array}$ & $\begin{array}{l}\text { Achenes } \\
\text { capitulum } \\
{ }^{1} \text { (No.) }\end{array}$ & $\begin{array}{c}\text { Sterility } \\
(\%)\end{array}$ & $\begin{array}{l}\text { 1000- } \\
\text { seed } \\
\text { weight } \\
\text { (g) }\end{array}$ & $\begin{array}{c}\text { Seed } \\
\text { yield } \\
\left(\mathbf{q} \mathbf{h a}^{-1}\right)\end{array}$ & $\begin{array}{c}\text { Oil } \\
\text { content } \\
(\%)\end{array}$ & $\begin{array}{c}\text { Oil yield } \\
\left(\mathbf{q} \mathbf{h a}^{-1}\right)\end{array}$ \\
\hline \multicolumn{8}{|c|}{ Nitrogen levels $\left(\mathrm{kg} \mathrm{ha}^{-1}\right)$} \\
\hline 40 & 12.42 & 318.4 & 6.38 & 57.62 & 20.2 & 40.9 & 82.6 \\
\hline 80 & 12.90 & 356.5 & 6.82 & 59.91 & 24.3 & 39.5 & 97.6 \\
\hline 120 & 13.20 & 363.3 & 8.15 & 60.0 & 25.5 & 39.0 & 101.2 \\
\hline $\mathrm{SE} \pm$ & 0.07 & 2.27 & 0.39 & 0.46 & 0.49 & 0.36 & 0.8 \\
\hline $\operatorname{CD}(p=0.05)$ & 0.22 & 6.56 & 1.14 & 1.33 & 1.38 & 1.04 & 2.5 \\
\hline \multicolumn{8}{|c|}{ Sulphur levels $\left(\mathrm{kg} \mathrm{ha}^{-1}\right)$} \\
\hline 30 & 12.75 & 336.4 & 6.81 & 58.17 & 22.5 & 39.2 & 88.7 \\
\hline 60 & 12.96 & 355.7 & 7.48 & 60.06 & 24.2 & 40.0 & 99.2 \\
\hline $\mathrm{SE} \pm$ & 0.06 & 1.85 & 0.32 & 0.37 & 0.40 & 0.29 & 0.7 \\
\hline $\mathrm{CD}(\mathrm{p}=0.05)$ & 0.18 & 5.35 & NS & 1.08 & 1.13 & 0.85 & 2.0 \\
\hline \multicolumn{8}{|c|}{ FYM levels $\left(t h a^{-1}\right)$} \\
\hline 0 & 12.56 & 321.4 & 6.06 & 57.71 & 21.6 & 39.0 & 85.0 \\
\hline 10 & 12.89 & 352.8 & 6.53 & 59.73 & 23.6 & 40.8 & 95.6 \\
\hline 20 & 13.11 & 364.0 & 8.83 & 60.08 & 24.9 & 40.7 & 101.1 \\
\hline $\mathrm{SE} \pm$ & 0.07 & 2.27 & 0.39 & 0.46 & 0.49 & 0.36 & 0.8 \\
\hline $\mathrm{CD}(\mathrm{p}=0.05)$ & 0.22 & 6.56 & 1.14 & 1.33 & 1.38 & NS & 2.5 \\
\hline
\end{tabular}

NS: non-significant 
Table 3: Interaction effect of nitrogen, sulphur and FYM levels on oil yield (q $h^{-1}$ ) of sunflower

a) Nitrogen and sulphur

\begin{tabular}{|c|c|c|c|c|c|c|}
\hline & \multicolumn{3}{|c|}{2009} & \multicolumn{3}{|c|}{2010} \\
\hline & $\mathbf{N}_{40}$ & $\mathbf{N}_{80}$ & $\mathbf{N}_{120}$ & $\mathbf{N}_{40}$ & $\mathbf{N}_{80}$ & $\mathbf{N}_{120}$ \\
\hline $\mathrm{S}_{30}$ & 73.4 & 92.3 & 98.1 & 76.9 & 93.5 & 96.3 \\
\hline \multirow[t]{3}{*}{$S_{60}$} & 92.4 & 102.3 & 105.4 & 86.5 & 102.8 & 105.0 \\
\hline & $\mathrm{SE} \pm$ & \multicolumn{2}{|c|}{$=1.54$} & & \multicolumn{2}{|c|}{$=0.92$} \\
\hline & $\mathrm{CD}$ & \multicolumn{2}{|c|}{$=4.44$} & \multicolumn{3}{|c|}{$\mathrm{CD}(\mathrm{p}=0.05) \quad=2.60$} \\
\hline
\end{tabular}

b) Nitrogen and FYM

\begin{tabular}{|c|c|c|c|c|c|c|}
\hline & \multicolumn{3}{|c|}{2009} & \multicolumn{3}{|c|}{2010} \\
\hline & $\mathrm{N}_{40}$ & $\mathrm{~N}_{80}$ & $\mathbf{N}_{120}$ & $\mathbf{N}_{40}$ & $\mathbf{N}_{80}$ & $\mathbf{N}_{120}$ \\
\hline $\mathbf{F}_{0}$ & 66.6 & 91.8 & 98.7 & 72.8 & 89.1 & 91.4 \\
\hline $\mathbf{F}_{10}$ & 86.8 & 96.5 & 101.3 & 85.0 & 101.1 & 102.7 \\
\hline \multirow[t]{3}{*}{$F_{20}$} & 95.7 & 104.0 & 105.6 & 87.7 & 104.5 & 108.1 \\
\hline & \multicolumn{2}{|c|}{$\mathrm{SE} \pm$} & 1.88 & \multicolumn{2}{|c|}{$\mathrm{SE} \pm$} & 1.13 \\
\hline & \multicolumn{2}{|c|}{$\mathrm{CD}(\mathrm{p}=0.05)$} & 5.44 & & $.05)$ & 3.26 \\
\hline
\end{tabular}

c) Sulphur and FYM

\begin{tabular}{|c|c|c|c|c|c|c|}
\hline & \multicolumn{3}{|c|}{2009} & \multicolumn{3}{|c|}{2010} \\
\hline & $\mathbf{F}_{\mathbf{0}}$ & $\mathbf{F}_{1}$ & $\mathbf{F}_{2}$ & $\mathbf{F}_{\mathbf{0}}$ & $\mathbf{F}_{1}$ & $\mathbf{F}_{2}$ \\
\hline $\mathrm{S}_{30}$ & 76.5 & 90.1 & 98.2 & 76.5 & 91.3 & 98.2 \\
\hline \multirow[t]{2}{*}{$S_{60}$} & 95.1 & 99.8 & 105.2 & 93.7 & 99.9 & 103.8 \\
\hline & $\begin{array}{l}\text { SE } \\
\text { CD }\end{array}$ & 5) = & & & $\mathrm{SE} \pm \quad=0.92$ & \\
\hline
\end{tabular}

